Original Research Paper

\title{
Clove (Syzygium aromaticum) and brown algae (Sargassum sp.) Supplementation on Nutritional Content of Payangka Fish Nugget (Ophieleotris aporos (Bleeker)
}

\author{
Wisda Nurjannah Abdullah ${ }^{1 *}$, Revolson Alexius Mege $^{2}$, Arrijani ${ }^{2}$, Mokosuli Yermia \\ Samuel ${ }^{2,3}$ \\ ${ }^{1}$ Program Studi Biologi, Program Pascasarjana, Universitas Negeri Manado, Indonesia. \\ ${ }^{2}$ Program Studi Biologi, Fakultas Matematika dan Ilmu Pengetahuan Alam, Universitas Negeri Manado, \\ Manado, Indonesia \\ ${ }^{3}$ Laboratorium Bioaktivitas dan Biologi Molekuler, Fakultas Matematika dan Ilmu Pengetahuan Alam, \\ Universitas Negeri Manado, Manado, Indonesia.
}

\begin{abstract}
Article History
Received : August $18^{\text {th }}, 2021$

Revised : August $30^{\text {th }}, 2021$

Accepted : September $07^{\text {th }}, 2021$

Published : September $17^{\text {th }}, 2021$

*Corresponding Author:

Wisda Nurjannah Abdullah,

Program Studi Biologi Program

Pascasarjana Universitas Negeri

Manado, Tomohon, Indonesia.

Email: wisdanurjannah@gmail
\end{abstract}

\begin{abstract}
Payangka fish (Ophieleotris aporos (Bleeker)) is one of the most common fish species in Lake Tondano, North Sulawesi. Due to the availability of this fish throughout the year, it is one of the types of fish consumed by many people. However, the economic value tends to be below. This study diversified payangka fish into nuggets with clove spice (Syzygium aromaticum) and brown seaweed (Sargassum $\mathrm{sp}$ ) supplementation. The research conducted aims to obtain a proximate profile and fatty acid content of payangka nugget. The research method used is an experimental laboratory method. The study consisted of preparing payangka fish, making payangka nuggets supplemented with clove and seaweed extracts, proximate analysis by gravimetric method and analysis of fatty acid content by gas chromatography method. The results showed that the supplemented payangka nugget had $67 \%$ water content, $0.80 \%$ ash content, $0.05 \%$ total fat, and $10.50 \%$ crude fiber. Omega 3 content is $4.75 \%$, while Omega 6 content is $34.16 \%$. Payangka fish nuggets that were supplemented had a higher nutritional content than those without supplementation. Payangka fish nuggets supplemented with clove extract and brown seaweed contain good dietary content.
\end{abstract}

Keywords: Payangka fish nuggets, cloves, brown algae, omega three, and omega 6.

\section{Pendahuluan}

Ikan payangka (Ophieleotris aporos (Bleeker)) merupakan jenis ikan yang paling banyak hidup di perairan danau Tondano, Minahasa Sulawesi Utara. Studi literasi penelitian biologi ikan payangka masih tergolong kurang (Olii et. al. 2017). Ikan Payangka merupakan ikan endemic Danau Tondano. Identifikasi molekuler ikan payangka menggunakan gen DNA mitokondria, memiliki kekerabatan genetik terdekat dengan Mogurnda sp. yang merupakan ikan endemik Danau Kutubu, Papua New Guinea (Wurarah \& Mokosuli, 2019). Reproduksi ikan payangka tergolong sangat cepat. Ikan payangka muda atau dikenal dengan sebutan nike (nama lokal), diolah menjadi makanan khas Suku Minahasa, Sulawesi Utara. Produksi payangka mencapai sekitar $35 \%$ dari seluruh produksi ikan dan mendominasi hasil tangkapan di danau Tondano. Ikan Payangka mempunyai warna yang sangat menarik. Ikan Jantan berwarna kuning kemerahan berbercak-bercak, sedangkan ikan payangka betina berwarna sedikit memucat, hijau keabuan sehingga sangat mudah untuk dibedakan (Bataragoa dan Tamananpo, 2009).

Ikan Payangka sering di konsumsi dalam keadaan segar dan sangat dinikmati oleh masyarakat, tapi sangat disayangkan nilai ekonomisnya rendah disebabkan produksi yang melimpah sepanjang tahun. Diversifikasi produk olahan ikan payangka akan meningkatkan nilai gizi dan ekonomis ikan payangka. Penelitian 
diversifikasi produk olahan ikan payangka masih sangat kurang. Tepung ikan payangka mengandung protein dengan komposisi asam amino yang sempurna. Tepung ikan payangka telah dikembangkan menjadi biscuit untuk makanan balita (Mantol, et. al. 2016). Selain bersifat hipoalergenik juga mengandung komposisi asam amino esensial yang setara dengan telur ayam (Mantol, et. al. 2016). Pada penelitian ini daging olahan ikan payangka menjadi nuget disuplementasi dengan ekstrak cengkih (Syzygium aromaticum) dan rumput laut coklat (Sargassum sp.). Selain meningkatkan kandungan gizi juga memiliki aktifitas biofarmaka. Cengkih sering digunakan sebagai pengharum mulut, mengobati bisul, sakit gigi, memperkuat lendir usus dan lambung serta menambah jumlah sel darah putih (Kaunang and Mokosuli, 2017). Cengkih dilaporkan memiliki aktivitas antibakteri (Xu et. al. 2016; Marchese et. al. 2017), antioksidan (Parham et. al. 2020). Lebih lanjut, Sargassum $s p$ mengandung alginate, protein, vitamin $\mathrm{C}$, tannin, iodine (Trono \& Ganzo, 1988), dan dilaporkan memiliki aktivitas antioksidan (Hidayati et. al. 2019; Tanna and Mizra, 2018; Norra et. al. 2016), antidiabetes (Firdaus et. al. 2015), antibacterial (Scania and Chasani, 2021; Nurilmala et. al. 2019; Pramesti et. al. 2017) dan antitumor (Kilawati and Islamy, 2019; Puspita et.al. 2017; Gomez-Zavaglia et. al. 2019; Hentati et. a. 2020; Dolorosa et. al. 2019)

Alasan dipilihnya produk olahan nugget adalah karena sangat disukai oleh masyarakat dari anak-anak hingga dewasa. Nugget merupakan salah satu produk olahan daging beku. Produk olahan nugget juga memiliki keistimewaan yaitu mempunyai daya simpan yang cukup lama. Penyimpanan dalam freezer bisa mencapai 2 minggu sampai 1 tahun (Suryatmoko, 2010). Daya simpan nuget meningkat dengan penambahan ekstrak tumbuhan seperti ekstrak teh (Pourashouri, et. al. 2020), bawang Dayak (Ambarani, 2019). Ekstrak tumbuhan dapat memberikan efek antioksidasi pada nuget ikan (Ali et. al. 2019; Sumarni, 2020) Sampai saat ini belum pernah dilaporkan kandungan gizi ikan payangka yang disuplementasi dengan ekstrak cengkih dan eksrak Sargassum sp. Suplementasi nuget payangka dengan ekstrak cengkih dan Sargassum sp. meningkatkan kandungan gizi dan aktifitas biofarmaka.

\section{Bahan dan Metode}

\section{Sampel}

Ikan payangka untuk pembuatan nuget diperoleh dari Danau Tondano, Minahasa. Cengkih (daun dan buah) diperoleh dari perkebunan cengkih Kombi, Minahasa sedangkan alga coklat diperoleh dari pantai Kombi MInahasa, Sulawesi Utara (Gambar 1). (a)

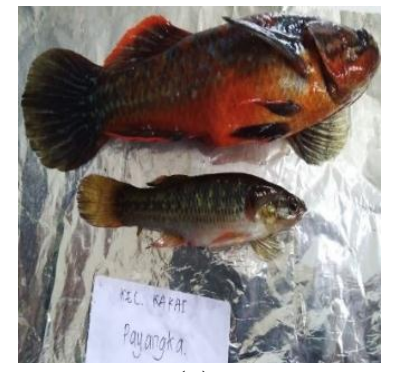

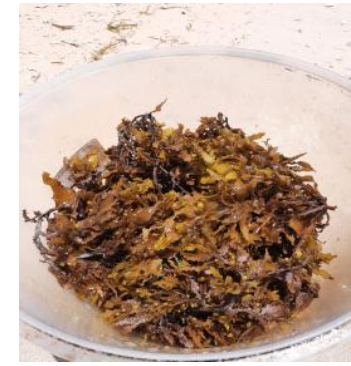

(b)



(c)

Gambar 1. (a). Ikan Payangka dari Danau Tondano, Minahasa (b). Alga coklat dari Pantai Kombi, Minahasa (c). Serbuk buah cengkih dari Minahasa, Sulawesi Utara.

Pembuatan nuget payangka, preparasi serbuk cengkih serbuk cengkih (Syzygium aromaticum) dan alga coklat (Sargassum sp.) dilakukan di Laboratorium Biofarmaka dan Biologi Molekuler FMIPA Universitas Negeri Manado. Analisis proksimat dan kandungan gizi di Laboratorium Penelitian dan Pengujian Terpadu (LPPT) UGM, Yogyakarta.

\section{Prosedur Penelitian}

Tahapan penelitian yaitu pengambilan sampel cengkih, alga laut dan ikan payangka, pembuatan Nugget ikan payangka yang disuplementasi cengkih dan alga laut, analisis kandungan proksimat nuget, analisis kandungan gizi dan analisis data penelitian (Gambar 2). 


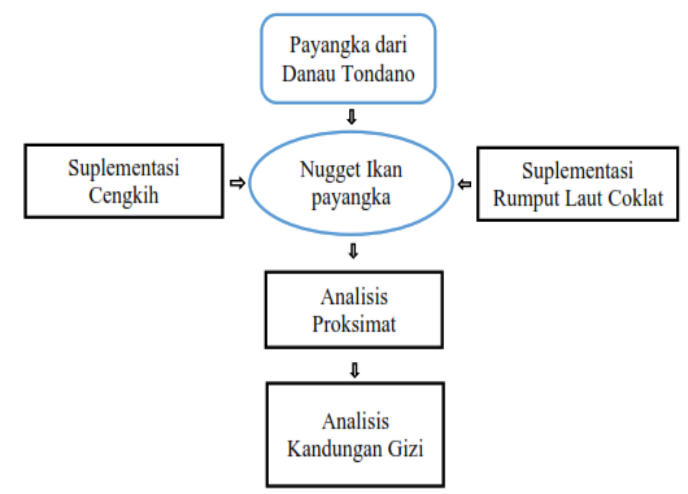

Gambar 2 Diagram Alir Tahapan Penelitian Nugget Ikan Payangka

\section{Pembuatan Nugget Ikan Payangka}

Ikan payangka yang digunakan memiliki panjang rata-rata $12 \mathrm{~cm}$ dengan berat rata-rata 200 gram per ekor. Payangka yang masih segar dikeluarkan jeroannya, dicuci pada air mengalir kemudian dilakukan proses leaching. Proses leaching untuk menghilangkan kotoran yang menempel pada tubuh ikan, menghilangkan darah dan mengurangi bau amis dari ikan. Kemudian dilakukan penyiangan untuk memisahkan daging ikan dari bagian yang tidak dapat dimakan (kepala, tulang, sirip dan ekor). Kemudian daging ikan payangka digiling sampai menjadi halus. Bawang merah dan bawang putih yang telah dihaluskan, batang bawang dan seledri yang diiris tipis, telur ayam, garam dan tepung terigu dicampur menjadi satu di baskom stainless. Setelah tercampur rata, adonan dibagi menjadi dua bagian. Bagian pertama yaitu olahan nugget tanpa suplementasi cengkih dan rumput laut coklat. Bagian kedua yaitu olahan nugget yang disuplementasi dengan cengkih dan rumput laut coklat. Serbuk cengkih yang digunakan sebanyak 3 gram dan rumput laut coklat sebanyak 5 gram. Setelah tercampur rata kemudian kedua bagian tersebut dikukus hingga setengah matang.

Dinginkan hasil kukusan, kemudian dipotong berbentuk kotak (Segi Empat) dengan ukuran rata-rata $5 \times 5 \mathrm{~cm}$ dan nugget berbentuk Stick (Panjang) dengan ukuran rata-rata $7 \times 2 \mathrm{~cm}$. Untuk potongan nugget yang tidak disuplementasi serbuk cengkih dan alga coklat berbentuk stick (Panjang). Sedangkan untuk potongan nugget ikan payangka yang disuplementasi serbuk cengkih dan rumput laut coklat dipotong berbentuk segi empat (Kotak). Setelah itu buat adonan celupannya menggunakan tepung terigu, air mineral dan garam secukupnya. Terakhir ambil potongan nugget tadi kemudian celupkan diadonan pencelup kemudian balur dengan tepung roti, setelah itu tinggal disimpan di kulkas dan digoreng saat akan dimakan. Proses-proses pengolahan nugget ikan payang terlihat pada gambar 3 berikut.

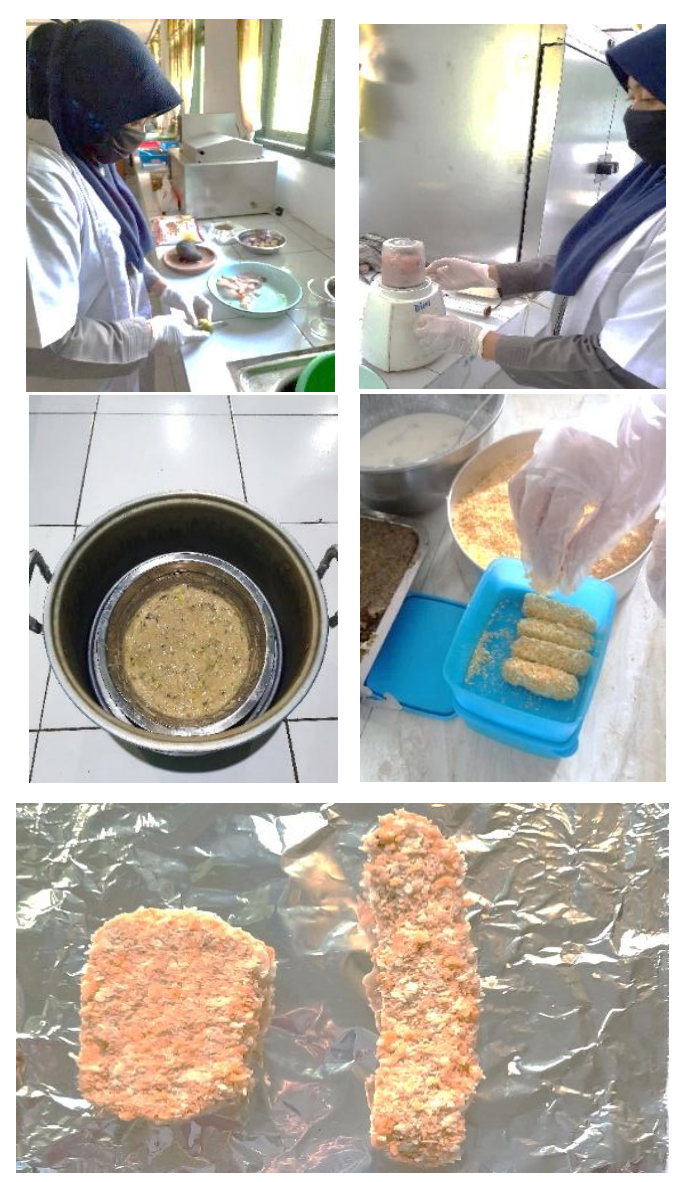

(Gambar 3 Proses Pembuatan Nugget Ikan Payangka).

\section{Analisis Kandungan Proksimat}

Analisis Proksimat meliputi analisis kadar air, kadar abu, kadar lemak total, dan serat kasar menggunakan metode Gravimetri.

\section{Analisis Kandungan Gizi (Asam lemak )}

Analisis kandungan Gizi (bioaktif) meliputi analisis asam lemak jenuh dan tidak jenuh, Omega 3, Omega 6 dan DHA dengan menggunakan metode GC MS (Kromatografi gas). 


\section{Hasil dan Pembahasan}

\section{A. Kadar Air dan Abu}

Hasil analisis kadar air sampel nuget segi empat adalah 67,46\% sedangkan kadar abu $0,80 \%$. Sedangkan rata rata kadar air sampel bentuk stick adalah $60,23 \%$, dan kadar abu
0,83\% (Tabel 1). Dengan demikian walaupun berat sampel tidak berbeda signifikan, nugget berbentuk segiempat memiliki kadar air dan kadar abu yang lebih tinggi dibandingkan nuget bentuk stick.

Tabel 1. Hasil Analisis Kadar Air dan Kadar Abu

\begin{tabular}{|c|c|c|c|c|c|c|c|}
\hline No & Kode & $\begin{array}{c}\text { Krus } \\
\text { Kosong } \\
\text { (g) } \\
\text { A }\end{array}$ & $\begin{array}{c}\text { Berat } \\
\text { sampel } \\
(\text { g) } \\
\text { B }\end{array}$ & $\begin{array}{c}\text { Berat } 105^{\circ} \\
\text { C } \\
(g) \\
\text { C }\end{array}$ & $\begin{array}{c}\text { Berat } \mathbf{6 0 0}^{0} \\
\text { C } \\
(\mathrm{g}) \\
\text { D } \\
\end{array}$ & $\begin{array}{c}\text { Kadar } \\
\text { air } \\
(\%)\end{array}$ & $\begin{array}{c}\text { Kadar } \\
\text { Abu } \\
(\%)\end{array}$ \\
\hline \multirow{3}{*}{1} & Segi & 34,1357 & 2,5149 & 34,9215 & 34,1577 & 68,75 & 0,87 \\
\hline & Empat & 38,3517 & 2,5976 & 39,2305 & 38,3706 & 66,17 & 0,73 \\
\hline & & & & & Rata-rata & 67,46 & 0,80 \\
\hline \multirow{3}{*}{2} & Sticl & 33,5086 & 2,5260 & 34,4982 & 33,5309 & 60,82 & 0,88 \\
\hline & Stick & 40,3486 & 2,5389 & 41,3736 & 40,3683 & 59,63 & 0,78 \\
\hline & & & & & Rata-rata & 60,23 & 0,83 \\
\hline
\end{tabular}

\section{B. Kadar Lemak}

Hasil uji kadar lemak nuget bentuk segi empat memiliki rata rata kadar lemak total $0,05 \%$ sedangkan nuget bentuk stick memiliki rata rata kadar lemak total 0,07\% (Tabel 2).

Tabel 2. Hasil analisis kadar lemak total

\begin{tabular}{llccccc}
\hline No & \multirow{2}{*}{ Kode } & $\begin{array}{c}\text { Berat } \\
\text { sampel } \\
(\mathbf{g})\end{array}$ & $\begin{array}{c}\text { Breaker } \\
\text { kosong } \\
(\mathbf{g})\end{array}$ & $\begin{array}{c}\text { Breaker } \\
\text { +lemak } \\
(\mathbf{g})\end{array}$ & $\begin{array}{c}\text { Kadar } \\
\text { lemak total } \\
(\boldsymbol{\%})\end{array}$ & $\begin{array}{c}\text { Rata-rata } \\
(\boldsymbol{\%})\end{array}$ \\
& & $\mathbf{A}$ & $\mathbf{B}$ & $\mathbf{C}$ & $\mathbf{D}$ & \\
\multirow{2}{*}{1} & \multirow{2}{*}{ Segi Empat } & 5,7264 & 63,6931 & 63,6963 & 0,06 & \multirow{2}{*}{0,05} \\
\hline \multirow{2}{*}{2} & \multirow{2}{*}{ Stick } & 5,6424 & 63,7256 & 63,7282 & 0,05 & \multirow{2}{*}{0,07} \\
\hline
\end{tabular}

\section{Serat Kasar}

Hasil analisis kandungan serat kasar, nuget bentuk segi empat memiliki rata rata $10.50 \%$ sedangkan nuget bentuk stick memiliki rata rata serat kasar 10,61\% (tabel 3).

Tabel 3. Hasil Analisis Serat Kasar

\begin{tabular}{|c|c|c|c|c|c|c|}
\hline No & Kode & $\begin{array}{c}\text { Berat } \\
\text { sampel } \\
(\text { g) } \\
\text { A }\end{array}$ & $\begin{array}{c}\text { Kertas } \\
\text { saring } \\
\text { kosong } \\
\text { (g) } \\
\text { B }\end{array}$ & $\begin{array}{c}\text { Kertas saring } \\
\text { kosong+kertas } \\
\text { saring kasar } \\
\text { (g) } \\
\text { C }\end{array}$ & $\begin{array}{c}\text { Kadar serat } \\
\text { kasar } \\
(\%) \\
\text { D }\end{array}$ & $\begin{array}{c}\text { Rata-rata } \\
(\%)\end{array}$ \\
\hline 1 & $\begin{array}{c}\text { Segi } \\
\text { Empat }\end{array}$ & $\begin{array}{l}1,0509 \\
1,0023\end{array}$ & $\begin{array}{l}0,4457 \\
0,4644\end{array}$ & $\begin{array}{l}0,5610 \\
0,5650\end{array}$ & $\begin{array}{l}10,97 \\
10,04\end{array}$ & 10,50 \\
\hline 2 & Stick & $\begin{array}{l}1,0507 \\
1,0337\end{array}$ & $\begin{array}{l}0,4200 \\
0,4083\end{array}$ & $\begin{array}{l}0,5288 \\
0,5206\end{array}$ & $\begin{array}{c}10,36 \\
10,86\end{array}$ & 10,61 \\
\hline
\end{tabular}

D. Kandungan Asam lemak

1. Nuget tanpa suplementasi ekstrak cengkih dan ekstrak alga coklat

Analisis kandungan asam lemak dengan metode Kromatografi gas pada nuget bentuk stick dan segi empat dilakukan pada sampel tanpa suplementasi ekstrak cengkih dan alga coklat dan sampel yang disuplementasi ekstrak cengkih dan alga coklat. Hasil analisis asam lemak tanpa suplementasi ekstrak cengkih dan alga coklat menunjukkan Kandungan asam lemak rantai pendek rata rata kurang dari $1 \%$ sedangkan kandungan asam lemak rantai medium miristat $(0,51 \%)$ sedangkan palmitat $(0,75 \%)$. 
Kandungan asam lemak tertinggi diperoleh pada asam lemak rantai Panjang yaitu persentasi asam M trans - 10 - elaidate $(32,66 \%)$, M cis-11-14eicosadienoate $(30,98 \%)$, M Heneicosenoate
$(24,58 \quad \%), \quad$ M cis-5-8-11-14-17eicosapentaenoate (1.54\%) dan M cis-4-7-10-1316-19-docosahexaenoate (1.24\%) (Tabel 4).

Tabel 4. Komposisi Asam Lemak Jenuh dan tidak Jenuh Nuget tanpa Suplementasi Ekstrak Cengkih dan Ekstrak Alga coklat

\begin{tabular}{|c|c|c|c|c|}
\hline No & Parameter Uji & Hasil & Satuan & Metode \\
\hline 1 & M Batyrate & 6.54 & $\%$ Relatif & Kromatrografi Gas \\
\hline 2 & M Hexanoate & $<0.1$ & $\%$ Relatif & Kromatrografi Gas \\
\hline 3 & M Octanoate & $<0.1$ & $\%$ Relatif & Kromatrografi Gas \\
\hline 4 & M Decanoate & $<0.1$ & $\%$ Relatif & Kromatrografi Gas \\
\hline 5 & M Undeaconoate & $<0.1$ & $\%$ Relatif & Kromatrografi Gas \\
\hline 6 & M Laurate & $<0.1$ & $\%$ Relatif & Kromatrografi Gas \\
\hline 7 & M Tridecanoate & 0.15 & $\%$ Relatif & Kromatrografi Gas \\
\hline 8 & M Myristate & 0.51 & $\%$ Relatif & Kromatrografi Gas \\
\hline 9 & Myristoleic Acid Methyl Ester & $<0.1$ & $\%$ Relatif & Kromatrografi Gas \\
\hline 10 & M Pentadecanoate & $<0.1$ & $\%$ Relatif & Kromatrografi Gas \\
\hline 11 & M cis -10 - Pentadecanoate & $<0.1$ & $\%$ Relatif & Kromatrografi Gas \\
\hline 12 & M Palmitate & 0.75 & $\%$ Relatif & Kromatrografi Gas \\
\hline 13 & M Palmitoleate & $<0.1$ & $\%$ Relatif & Kromatrografi Gas \\
\hline 14 & M Heptadecanoate & $<0.1$ & $\%$ Relatif & Kromatrografi Gas \\
\hline 15 & M cis-10-Heptadecanoate & $<0.1$ & $\%$ Relatif & Kromatrografi Gas \\
\hline 16 & M Streate & $<0.1$ & $\%$ Relatif & Kromatrografi Gas \\
\hline 17 & M trans-10-elaidate & 32.66 & $\%$ Relatif & Kromatrografi Gas \\
\hline 18 & $\mathrm{M}$ cis-9-oleate & $<0.1$ & $\%$ Relatif & Kromatrografi Gas \\
\hline 19 & M Linolelaidate & $<0.1$ & $\%$ Relatif & Kromatrografi Gas \\
\hline 20 & M Linoleate & $<0.1$ & $\%$ Relatif & Kromatrografi Gas \\
\hline 21 & Gamma-Linolenic Acid Methyl Ester & $<0.1$ & $\%$ Relatif & Kromatrografi Gas \\
\hline 22 & M Aracidate & $<0.1$ & $\%$ Relatif & Kromatrografi Gas \\
\hline 23 & M Linolenate & $<0.1$ & $\%$ Relatif & Kromatrografi Gas \\
\hline 24 & M cis-11-eicosenoate & $<0.1$ & $\%$ Relatif & Kromatrografi Gas \\
\hline 25 & M Heneicosenoate & 24.58 & $\%$ Relatif & Kromatrografi Gas \\
\hline 26 & M cis-11-14-eicosadienoate & 30.98 & $\%$ Relatif & Kromatrografi Gas \\
\hline 27 & M Behenate+M cis-11-14-17-eicosatrienoate & $<0.1$ & $\%$ Relatif & Kromatrografi Gas \\
\hline 28 & M cis-8-11-14-eicesatrienoate & 1.06 & $\%$ Relatif & Kromatrografi Gas \\
\hline 29 & M cis-13-docosenoate & $<0.1$ & $\%$ Relatif & Kromatrografi Gas \\
\hline 30 & M cis-5-8-11-14-17-eicosapentaenoate & $<0.1$ & $\%$ Relatif & Kromatrografi Gas \\
\hline 31 & M Tricosanoate & $<0.1$ & $\%$ Relatif & Kromatrografi Gas \\
\hline 32 & $\mathrm{M}$ cis-13-16-docosadienoate & $<0.1$ & $\%$ Relatif & Kromatrografi Gas \\
\hline 33 & M cis-5-8-11-14-17-eicosapentaenoate & 1.54 & $\%$ Relatif & Kromatrografi Gas \\
\hline 34 & M Lignocerate & $<0.1$ & $\%$ Relatif & Kromatrografi Gas \\
\hline 35 & M Nervonate & $<0.1$ & $\%$ Relatif & Kromatrografi Gas \\
\hline 36 & M cis-4-7-10-13-16-19-docosahexaenoate & 1.24 & $\%$ Relatif & Kromatrografi Gas \\
\hline
\end{tabular}

\section{Omega 3 dan Omega 6}

Hasil analisis kandungan asam lemak tak jenuh omega 3, diperoleh kandungan EPA $(1,54 \%)$ dan DHA $(1,24 \%)$ (Tabel5). Sedangkan kandungan Omega 6 diperoleh Asam
Eicosadienoat (30,98 \%) dan $\mathrm{M}$ cis-8,11,14 Eicosadienoat $(1,06 \%)$ (tabel 6). Asam Eicosadienoat $(2,10 \%)$. Kadar omega 3 2,78\% sedangkan kadar omega $632,06 \%$.

Tabel 5. Hasil Analisis Omega 3 Nugget Stick

\begin{tabular}{llccc}
\hline No & \multicolumn{1}{c}{ Parameter Uji } & Hasil & Satuan & Metode \\
\hline 1 & Asam Linolenate & $<0.1$ & $\%$ Relatif & Kromatrografi Gas \\
2 & Asam Eicosatrienoate & $<0.1$ & $\%$ Relatif & Kromatrografi Gas \\
3 & Asam Arachidonat & $<0.1$ & $\%$ Relatif & Kromatrografi Gas \\
4 & EPA & 1.54 & $\%$ Relatif & Kromatrografi Gas \\
5 & DHA & 1.24 & $\%$ Relatif & Kromatrografi Gas \\
\hline \multicolumn{4}{c}{ Kadar Omega 3 yaitu 2.78 \% Relatif } \\
\hline \multicolumn{4}{c}{}
\end{tabular}


Tabel 6. Hasil Analisis Omega 6 Nugget Stick

\begin{tabular}{llcll}
\hline No & \multicolumn{1}{c}{ Parameter Uji } & Hasil & Satuan & Metode \\
\hline 1 & Asam Linoleat & $<0.1$ & \%Relatif & Kromatrografi Gas \\
2 & Asam Eicosadienoat & 30.98 & \%Relatif & Kromatrografi Gas \\
3 & M cis-8,11,14 Eicosadienoat & 1.06 & \%Relatif & Kromatrografi Gas \\
\hline \multicolumn{4}{c}{ Kadar Omega 6 yaitu 32,04 \% Relatif } \\
\hline
\end{tabular}

\section{Nuget dengan suplementasi ekstrak} cengkih dan ekstrak alga coklat

Hasil analisis asam lemak nuget yang disuplementasi ekstrak cengkih dan ekstrak alga coklat menunjukkan kandungan asam lemak rantai pendek tertinggi $\mathrm{M}$ Batyrate $(8,12 \%)$.
Sedangkan kandungan asam lemak rantai medium tertinggi M Palmitate $(3,33 \%)$. Lebih lanjut, kandungan asam lemak rantai Panjang tertinggi adalah $\mathrm{M}$ cis-8-11-14-eicesatrienoate $(32,06 \%)$ (Tabel 7).

Tabel 7. Hasil Analisis Lemak Jenuh dan Tidak Jenuh Nugget Segi Empat

\begin{tabular}{|c|c|c|c|c|}
\hline No & Parameter Uji & Hasil & Satuan & Metode \\
\hline 1 & M Batyrate & 8.12 & $\%$ Relatif & Kromatrografi Gas \\
\hline 2 & M Hexanoate & $<0.1$ & $\%$ Relatif & Kromatrografi Gas \\
\hline 3 & M Octanoate & $<0.1$ & $\%$ Relatif & Kromatrografi Gas \\
\hline 4 & M Decanoate & $<0.1$ & $\%$ Relatif & Kromatrografi Gas \\
\hline 5 & M Undeaconoate & $<0.1$ & $\%$ Relatif & Kromatrografi Gas \\
\hline 6 & M Laurate & $<0.1$ & $\%$ Relatif & Kromatrografi Gas \\
\hline 7 & M Tridecanoate & 0.36 & $\%$ Relatif & Kromatrografi Gas \\
\hline 8 & M Myristate & 0.32 & $\%$ Relatif & Kromatrografi Gas \\
\hline 9 & Myristoleic Acid Methyl Ester & $<0.1$ & $\%$ Relatif & Kromatrografi Gas \\
\hline 10 & M Pentadecanoate & $<0.1$ & $\%$ Relatif & Kromatrografi Gas \\
\hline 11 & $M$ cis -10 - Pentadecanoate & $<0.1$ & $\%$ Relatif & Kromatrografi Gas \\
\hline 12 & M Palmitate & 3.33 & $\%$ Relatif & Kromatrografi Gas \\
\hline 13 & M Palmitoleate & $<0.1$ & $\%$ Relatif & Kromatrografi Gas \\
\hline 14 & M Heptadecanoate & $<0.1$ & $\%$ Relatif & Kromatrografi Gas \\
\hline 15 & M cis-10-Heptadecanoate & $<0.1$ & $\%$ Relatif & Kromatrografi Gas \\
\hline 16 & M Streate & $<0.1$ & $\%$ Relatif & Kromatrografi Gas \\
\hline 17 & $\mathrm{M}$ trans-10-elaidate & 0.63 & $\%$ Relatif & Kromatrografi Gas \\
\hline 18 & M cis-9-oleate & $<0.1$ & $\%$ Relatif & Kromatrografi Gas \\
\hline 19 & M Linolelaidate & $<0.1$ & $\%$ Relatif & Kromatrografi Gas \\
\hline 20 & M Linoleate & $<0.1$ & $\%$ Relatif & Kromatrografi Gas \\
\hline 21 & Gamma-Linolenic Acid Methyl Ester & $<0.1$ & $\%$ Relatif & Kromatrografi Gas \\
\hline 22 & M Aracidate & $<0.1$ & $\%$ Relatif & Kromatrografi Gas \\
\hline 23 & M Linolenate & $<0.1$ & $\%$ Relatif & Kromatrografi Gas \\
\hline 24 & M cis-11-eicosenoate & $<0.1$ & $\%$ Relatif & Kromatrografi Gas \\
\hline 25 & M Heneicosenoate & 0.86 & $\%$ Relatif & Kromatrografi Gas \\
\hline 26 & M cis-11-14-eicosadienoate & 2.10 & $\%$ Relatif & Kromatrografi Gas \\
\hline 27 & M Behenate $+\mathrm{M}$ cis-11-14-17-eicosatrienoate & 26.49 & $\%$ Relatif & Kromatrografi Gas \\
\hline 28 & $\mathrm{M}$ cis-8-11-14-eicesatrienoate & 32.06 & $\%$ Relatif & Kromatrografi Gas \\
\hline 29 & M cis-13-docosenoate & $<0.1$ & $\%$ Relatif & Kromatrografi Gas \\
\hline 30 & M cis-5-8-11-14-17-eicosapentaenoate & $<0.1$ & $\%$ Relatif & Kromatrografi Gas \\
\hline 31 & M Tricosanoate & $<0.1$ & $\%$ Relatif & Kromatrografi Gas \\
\hline 32 & M cis-13-16-docosadienoate & $<0.1$ & $\%$ Relatif & Kromatrografi Gas \\
\hline 33 & M cis-5-8-11-14-17-eicosapentaenoate & 3.03 & $\%$ Relatif & Kromatrografi Gas \\
\hline 34 & M Lignocerate & $<0.1$ & $\%$ Relatif & Kromatrografi Gas \\
\hline 35 & M Nervonate & $<0.1$ & $\%$ Relatif & Kromatrografi Gas \\
\hline 36 & $M$ cis-4-7-10-13-16-19-docosahexaenoate & 1.72 & $\%$ Relatif & Kromatrografi Gas \\
\hline
\end{tabular}

\section{Omega 3 dan Omega 6}

Hasil analisis kandungan asam lemak tak jenuh omega 3 menunjukkan kandungan tertinggi adalah EPA $(3,03 \%)$ dan DHA $(1,72 \%)$. Sedangkan Kandungan asam lemak tak jenuh omega 6 tertinggi adalah $M$ cis-8,11,14 
Eicosadienoat (32,06\%) dan Asam

Eicosadienoat (2,10\%). Kadar omega $34,75 \%$

sedangkan kadar omega $634,16 \%$.

Tabel 8. Hasil Analisis Omega 3 Nugget Segi Empat

\begin{tabular}{llccc}
\hline No & \multicolumn{1}{c}{ Parameter Uji } & Hasil & Satuan & Metode \\
\hline 1 & Asam Linolenate & $<0.1$ & $\%$ Relatif & Kromatrografi Gas \\
2 & Asam Eicosatrienoate & $<0.1$ & $\%$ Relatif & Kromatrografi Gas \\
3 & Asam Arachidonat & $<0.1$ & $\%$ Relatif & Kromatrografi Gas \\
4 & EPA & 3.03 & $\%$ Relatif & Kromatrografi Gas \\
5 & DHA & 1.72 & $\%$ Relatif & Kromatrografi Gas \\
\hline \multicolumn{4}{r}{ Kadar Omega 3 yaitu 4.75 \% Relatif } \\
\hline \multicolumn{5}{c}{}
\end{tabular}

Tabel 9. Hasil Analisis Omega 6 Nugget Segi Empat

\begin{tabular}{llcll}
\hline No & \multicolumn{1}{c}{ Parameter Uji } & Hasil & Satuan & Metode \\
\hline 1 & Asam Linoleat & $<0.1$ & \%Relatif & Kromatrografi Gas \\
2 & Asam Eicosadienoat & 2.10 & $\%$ Relatif & Kromatrografi Gas \\
3 & M cis-8,11,14 Eicosadienoat & 32.06 & $\%$ Relatif & Kromatrografi Gas \\
\hline \multicolumn{4}{c}{ Kadar Omega 6 yaitu 34,16 \%Relatif } \\
\hline
\end{tabular}

\section{Pembahasan}

Suplementasi serbuk buah cengkih dan alga laut berpengaruh positif pada karakteristik fisikokimia nuget ikan payangka. Kadar air nuget ikan berdasarkan standar SNI 60-65 \% (Gasperzs, 2018). Dengan demikian kadar nuget ikan payangka yang disuplementasi cengkih dan rumput laut masih memenuhi standar. Kadar abu menunjukan kandungan nutrient. Hasil analisis kadar abu nuget payangka dengan rata rata $0,8 \%$ menunjukkan kandungan nutrient yang tinggi pada nuget ikan payangka yang disuplementasi cengkih dan rumput laut. Standar SNI untuk kandungan lemak nuget ikan dibawah 20\% (Gasperzs, 2018), hasil penelitian ini menunjukkan nuget ikan payangka uang disuplementasi cengkih dan rumput laut menunjukkan kandungan kadar lemak rata rata $0,05 \%$. Dengan demikian nuget ikan payangka tersuplementasi cengkih dan rumput laut memenuhi standar SNI. Rata kandungan serat kasar nuget ikan payangka tersuplementasi cengkih dan alga coklat $10,50 \%$, memenuhi syarat nuget ikan SNI.

Suplementasi bahan tumbuhan terhadap nuget dalam berbagai penelitian meningkatkan nilai gizi nuget ikan. Nuget ikan nike dengan penambahan tempe mempengaruhi kandungan asam lemak tak jenuh seperti omega 3 dan omega 6 (Liputo et. al. 2019). Substitusi bayam meningkatkan kandungan gizi nuget ikan tongkol (Ruaida and Soumokil (2020). Penambahan ekstrak bawang Dayak meningkatkan kemampuan antioksidan nuget ikan lele (Roman et. al. 2020). Penambahan ekstrak tumbuhan yang mengandung senyawa polifenol tidak mempengaruhi komposisi asam lemak tak jenuh pada nuget ikan (Ali et. al. 2019). Penambahan daun kelor pada nuget ikan lele k mempenaruhi sifat fisikokimia, kandungan protein dan tekstur nuget ikan lele (Solichah et. al. 2021). Penambahan ekstrak Ocimum gratissimum, Vernonia amygdalina meningkatkan kandungan proksimat Snak ikan Sarotherodon galilaeus (Ileogben and Ogini, 2018). Penambahan fukosantin Sargassum sp. meningkatkan nilai a, b serta menurunkan nilai $\mathrm{L}$, nilai peroksida dan nilai $\mathrm{pH}$ sosis ikan lele selama penyimpanan (Aditya, 2019).

Berdasarkan hasil penelitian, penambahan cengkih dan alga coklat meningkatkan kandungan asam lemak tak jenuh rantai Panjang nuget ikan payangka. Nuget ikan payangka yang disuplementasi cengkih dan alga coklat memiliki kandungan omega 3 dan omega 6 yang lebih tinggi dibandingkan tanpa penambahan cengkih dan alga coklat. Omega 3 merupakan polyunsaturated fatty acid yang tidak dapat diproduksi oleh tubuh, sehingga diperoleh dari makanan. Hasil penelitian ini, nuget payangka yang disuplementasi cengkih dan alga coklat memiliki kandungan Eicosapentaenoic acid (EPA) 3,03 \% . EPA berperan dalam stimulasi system imun dan mengendalikan peradangan 
(Ilag, 2018; Rogero et. al. 2020; Szabó et. al. 2020). EPA merupakan asam lemak yang dianjurkan pada penderita COVID 19 (Rogero et. al. 2020). Selain kandungan omega 3 EPA, juga diperoleh kandungan Docosahexaenoic (DHA) yang signifikan pada nuget ikan payangka tersuplementasi cengkih dan alga coklat yaitu $1,72 \%$. DHA termasuk komponen utama yang membangun $8 \%$ berat otak dan mencegah gangguan fungsi otak seperti demensia (Szabó et. al. 2020; Calder, 2020). Dengan demikian nuget ikan payangka yang disuplementasi cengkih dan alga coklat potensial dikembangkan sebagai sumber makanan bergizi tinggi.

\section{Ucapan Terima Kasih}

Peneliti mengucapkan terima kasih kepada pimpinan dan pranata laboratorium Biologi FMIPA Universitas Negeri Manado dan Laboratorium Terpadu LPPT Universitas Gadjah Mada yang telah membantu pelaksanaan penelitian ini.

\section{Referensi}

Aditya, N. W. (2019). Fortifikasi Sosis Ikan Lele Dengan Penambahan Pigmen Fukosantin Dari Rumput Laut Sargassum $S p$ (Doctoral dissertation, Universitas Airlangga).

Ambarani, D. I. (2019). Pengaruh penambahan ekstrak bawang dayak (eleutherine palmifolia merr.) Terhadap makronutrient, alkaloid dan organoleptik nugget lele (Doctoral dissertation, Universitas Darussalam Gontor).

Ali, M., Imran, M., Nadeem, M., Khan, M. K., Sohaib, M., Suleria, H. A. R., \& Bashir, R. (2019). Oxidative stability and Sensoric acceptability of functional fish meat product supplemented with plant- based polyphenolic optimal extracts. Lipids in health and disease, 18(1), 1-16.

Astawan, M. (2004). Ikan yang Sedap dan Bergizi. Tiga Serangkai. Solo.

Bambang Mulyadi. (2019). Nugget Is a Big Market. Jakarta: PT Gramedia Pustaka Utama.
Bataragoa N. E. Dan Tamanampo J. F. W. S., (2009). Potensi Reproduksi Ikan Payangka (Ophieleotris aporos) dari Danau dan Sungai. Pacific Journal. April 2009. Vol 3(3) : 442-446.

Calder, P. C. (2020). n-3 PUFA and inflammation: from membrane to nucleus and from bench to bedside. Proceedings of the Nutrition Society, 79(4), 404-416.

Dolorosa, M. T., Purwaningsih, S., Anwar, E., \& Hidayat, T. (2019, May). Tyrosinase inhibitory activity of Sargassum plagyophyllum and Eucheuma cottonii methanol extracts. In IOP Conference Series: Earth and Environmental Science, 278(1), p. 012020). IOP Publishing.

Firdaus, M., Nurdiani, R., \& Prihanto, A. A. (2015). Antihyperglycemic of Sargassum sp. extract. Marine algae extracts: Processes, products, and applications, 381-394.

Gasperzs, F. (2018). Kandungan Nutrisi Dan Mutu Organoleptik Nugget Tetelan Ikan Tuna (Thunnus sp.) Dengan Substitusi Kentang. Majalah BIAM, 14(2), 74-80.

Gomez-Zavaglia, A., Prieto Lage, M. A., Jimenez-Lopez, C., Mejuto, J. C., \& Simal-Gandara, J. (2019). The potential of seaweeds as a source of functional ingredients of prebiotic and antioxidant value. Antioxidants, 8(9), 406.

Hentati, F., Tounsi, L., Djomdi, D., Pierre, G., Delattre, C., Ursu, A. V., ... \& Michaud, P. (2020). Bioactive polysaccharides from seaweeds. Molecules, 25(14), 3152.

Hidayati, J. R., Yudiati, E., Pringgenies, D., Arifin, Z., \& OktaviyantI, D. T. (2019). Antioxidant activities, total phenolic compound and pigment contents of tropical Sargassum sp. extract, macerated in different solvents polarity. Jurnal Kelautan Tropis, 22(1), 73-80.

Ileogben, T. A., \& Oginni, O. (2018). Nutritional Analysis of Fish (Sarotherodon galilaeus) Snack with and without the Fortification of Plant (Ocimum gratissimum, Vernonia amygdalina and Ocimum gratissimum 
plus Vernonia amygdalina)

Extracts. Bioscience Methods, 9.

Makmur., et al. (2015). Karakteristik Lingkungan, Keanekaragaman Jenis Ikan dan Aktivitas Penangkapan Sumber daya Ikan Danau Tondano Sulawesi Utara.

Ilag, L. L. (2018). Are long-chain polyunsaturated fatty acids the link between the immune system and the microbiome towards modulating cancer?. Medicines, 5(3), 102.

Kaunang, E. N. S., \& Mokosuli Y. S. (2017). Botanical and phytochemical constituents of several medicinal plants from mount Klabat north Minahasa. Journal of Medicinal Plants Studies, 5(2), 29-35.

Kilawati, Y., \& Islamy, R. A. (2019). The antigenotoxic activity of brown seaweed (Sargassum sp.) extract against total erythrocyte and micronuclei of Tilapia Oreochromis niloticus exposed by methomyl-base pesticide. The Journal of Experimental Life Science, 9(3), 205-210.

Liputo, S. A., Berhimpon, S., \& Fatimah, F. (2013). Analisa Nilai Gizi Serta Komponen Asam Amino Dan Asam Lemak Dari Nugget Ikan Nike (Awaous melanocephalus) DENGAN PENAMBAHAN TEMPE. CHEMISTRY PROGRESS, 6(1). DOI: https://doi.org/10.35799/cp.6.1.2013.2070

Marchese, A., Barbieri, R., Coppo, E., Orhan, I. E., Daglia, M., Nabavi, S. F., ... \& Ajami, M. (2017). Antimicrobial activity of eugenol and essential oils containing eugenol: A mechanistic viewpoint. Critical reviews in microbiology, 43(6), 668-689.

Montol, A. B., Momongan, N. R., \& Djendra, I. M. (2016). Analisis Nilai Gizi Dan Tingkat Penerimaan Konsumen Terhadap Formula Biscuit Tepung Ikan Payangka (OPHIELEOTRIS APOROS). Jurnal GIZIDO, 8(1), 1-14.

Norra, I., Aminah, A., \& Suri, R. (2016). Effects of drying methods, solvent extraction and particle size of Malaysian brown seaweed,
Sargassum sp. on the total phenolic and free radical scavenging activity. International Food Research Journal, 23(4).

Nurilmala, M., Anwar, E., Luthfiyana, N., \& Hidayat, T. (2017). Identification of Bioactive Compounds of Seaweed Sargassum sp. and Eucheuma cottonii Doty as a Raw Sunscreen Cream: Bioactive Compounds of Seaweed as a Raw Sunscreen Cream. Proceedings of the Pakistan Academy of Sciences: B. Life and Environmental Sciences, 54(4), 311-318.

Olii A.H., Sahami F, \& hamzah S. N. (2017). Pengembangan potensi sumberdaya perikanan nike (awaous sp.) Berbasis budaya lokal di kota gorontalo. Laporan Penelitian Unggulan Perguruan Tinggi, Universitas Negeri Gorontalo.

Parham, S., Kharazi, A. Z., Bakhsheshi-Rad, H. R., Nur, H., Ismail, A. F., Sharif, S., ... \& Berto, F. (2020). Antioxidant, antimicrobial and antiviral properties of herbal materials. Antioxidants, 9(12), 1309.

Pourashouri, P., Shabanpour, B., Kordjazi, M., \& Jamshidi, A. (2020). Characteristic and shelf life of fish sausage: fortification with fish oil through emulsion and gelled emulsion incorporated with green tea extract. Journal of the Science of Food and Agriculture, 100(12), 4474-4482.

Pramesti, R., Setyati, W. A., Zainuddin, M., \& Puspita, M. (2017). Bioecology of Sargassum sp. and its Extract Bioactivity as Anti-MDR Bacteria. ILMU KELAUTAN: Indonesian Journal of Marine Sciences, 22(4), 185.

Puspita, M., Déniel, M., Widowati, I., Radjasa, O. K., Douzenel, P., Marty, C., ... \& Bourgougnon, N. (2017). Total phenolic content and biological activities of enzymatic extracts from Sargassum muticum (Yendo) Fensholt. Journal of applied phycology, 29(5), 2521-2537.

Rogero, M. M., Leão, M. D. C., Santana, T. M., de MB Pimentel, M. V., Carlini, G. C., da Silveira, T. F., ... \& Castro, I. A. (2020). Potential benefits and risks of omega-3 
fatty acids supplementation to patients with COVID-19. Free Radical Biology and Medicine.

Ruaida, N., \& Soumokil, O. (2020). Analisis Zat Besi dan Daya Terima Pada Nuget Ikan Tongkol Dengan Substitusi Bayam. Global Health Science (GHS), 5(1), 4449.

Rohman, Y., Fathimah, F., \& Nurohmi, S. (2020). Pengaruh penambahan ekstrak bawang Dayak (Eleutherine americana Merr.) pada senyawa flavonoid dan aktivitas antioksidan nuget ikan lele. Darussalam Nutrition Journal, 4(1), 1-6.

Sastrohamidjojo. H, (2002). Kimia Minyak Atsiri, Edisi I, Gajah Mada University Press, Yokyakarta.

Scania, A. E. and Chasani, A. R. 2021. The antibacterial effect of phenolic compounds from three species of marine macroalgae. Biodiversitas Vol. 22, (6) June 2021: 3412-3417.

Szabó, Z., Marosvölgyi, T., Szabó, É., Bai, P., Figler, M., \& Verzár, Z. (2020). The potential beneficial effect of EPA and DHA supplementation managing cytokine storm in coronavirus disease. Frontiers in physiology, 11, 752 .

Solichah, E., Iwansyah, A. C., Pramesti, D., Desnilasari, D., Agustina, W., Setiaboma, W., \& Herminiati, A. (2021). Evaluation of physicochemical, nutritional, and organoleptic properties of nuggets based on moringa (Moringa oleifera) leaves and giant catfish (Arius thalassinus). Food Science and Technology.

Sumarni N. (2020). Pengaruh Penambahan Daun Kelor (Moringa Aleifera L) Pada Nugget Ikan Tongkol (Euthynnus Affinis) Terhadap Mutu Organoleptik Dan Kandungan Zat Gizi Sebagai Makanan Alternatif Tinggi Zat Besi (Doctoral dissertation, Universitas Perintis Indonesia).

Suparmi \& Sahri A. (2019). Mengenal Potensi Rumput Laut: Kajian Pemanfaatan Sumber Daya Rumput Laut dari Aspek Industri dan Kesehatan. Universitas Diponegoro. Semarang.
Suryatmoko. 2010. Kajian Penambahan Tepung Tapioka dan Susu Skim Terhadap Penerimaan Konsumen Pada Produk Nugget Ikan Mas. Unisla.

Sutriyono (2017). Budidaya Cengkih. Universitas Merdeka Surabaya.

Widyartini, D. S. \& A. I. Insan. (2004). Produksi Rumput Laut Gracilaria gigas dan Gracilaria verrucosa Dengan Sistem Budidaya Yang Berbeda di Perairan Tambak Kebumen. Laporan Penelitian Fakultas biologi Unsoed, Purwokerto.

Tanna, B., \& Mishra, A. (2018). Metabolites unravel nutraceutical potential of edible seaweeds: An emerging source of functional food. Comprehensive reviews in food science and food safety, 17(6), 16131624.

Wurarah M. \& Mokosuli Y.S. (2019). Development of Audio Visual Learning Mediaof Biology on the Concept of DNA, Based on the Results of Molecular Identification of Payangka Fish from Lake Tondano. State University Of Manado. 8(1), 1-7.

Xu, J. G., Liu, T., Hu, Q. P., \& Cao, X. M. (2016). Chemical composition, antibacterial properties and mechanism of action of essential oil from clove buds against Staphylococcus aureus. Molecules, 21(9), 1194. 